\title{
Paclobutrazol Soaked Marigold, Geranium, and Tomato Seeds Produce Short Seedlings
}

\author{
C.C. Pasian and M.A. Bennett \\ Department of Horticulture and Crop Science, The Ohio State University, \\ 2001 Fyffe Court, Columbus, OH 43210
}

Additional index words. Tagetes patula, Pelargonium sp., Lycopersicon esculentum, Bonzi ${ }^{\mathrm{TM}}$

Abstract. Bedding plants and many vegetable crop seeds are often sown in plug trays. Some crops, like marigold (Tagetes sp. L.), tend to stretch early after germination, especially if grown in low light environments. By the time growers apply plant growth regulators (PGRs), stretching of the hypocotyl has already occurred and seedling applications are ineffective. Seedling height may be controlled by applying the plant growth regulator directly to the seed. Seeds of 'Bonanza Gold' marigold (Tagetes patula L.), 'Cherry Orbit' geranium (Pelargonium ${ }_{\{x t i m e s} \mid$ hortorum L.H. Bailey), and 'Sun 6108' tomato (Lycopersicon esculentum Mill.) were soaked for 6, 16, or 24 hours in paclobutrazol solutions of 0,500 , or $1000 \mathrm{mg} \cdot \mathrm{L}^{-1}$. After the soak treatment, seeds were dried for 24 hours prior to laboratory germination testing or sowing in plug trays. Percentage of emergence and seedling height were measured 16, 26, and 36 days after sowing. Laboratory germination of treated seeds was less than that of the control, which was attributed to the PGR being concentrated around the seed on the blotters. In contrast, seedling survival was unaffected in plugs. The higher concentration of PGR and longer times of soaking increased growth regulation, but also inhibited emergence of geraniums (71\% vs. $99 \%)$. When seeds were imbibed 6, 16, or 24 hours, growth restriction was $31 \%, 31 \%$, and $40 \%$, respectively, for tomato, $61 \%, 37 \%$, and $76 \%$, respectively, for geranium and $30 \%, 38 \%$, and $41 \%$, respectively, for marigold. These results indicate that PGR application to geranium, marigold, and tomato seeds may be feasible using a 6- or 16-hour soak in 500

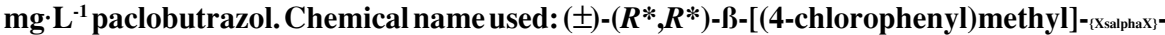
(1,1-dimethyl)-1H-1,2,4-triazole-1-ethanol (paclobutrazol).

Production of bedding plants and vegetable transplants in plug trays involves a systems approach to deal with many factors and inputs. A common challenge for transplant producers is height control. Many plant growth regulators (PGRs) are applied as foliar sprays or substrate drenches (Barrett and Nell, 1989; Dasoju et al., 1998; Whipker and Hammer, 1997). Other delivery systems for growth retardants include PGR-impregnated clay pots, treated fertilizer spikes, gels, tablets, sub-application, and media spray (Barrett, 2000; Barrett et al., 1994; Einert, 1976; Sanderson et al., 1988). Limitations were reported for the various application methods. For example, soil drenches with growth retardants are often preferred over foliar sprays due to minimal drift of active ingredient, but growing media components by paclobutrazol

Received for publication 27 Mar. 2000. Accepted for publication 19 Jan. 2001. Salaries and research support were provided in part by State and Federal Funds appropriated to the Ohio Agricultural Research and Development Center, The Ohio State Univ. No endorsement is intended for products mentioned in this article, nor is criticism meant for products not mentioned. We thank Andrew Evans, Elaine Grassbaugh, and Monica Kmetz-Gonzalez for their excellent technical assistance during this study. The cost of publishing this paper was defrayed in part by the payment of page charges. Under postal regulations, this paper therefore must be hereby marked advertisement solely to indicate this fact. interactions are significant (Million et al., 1998). Application of PGRs directly to seeds may circumvent some of these limitations for bedding plant production. Organic solvents such as acetone and ethanol have been used to deliver various PGRs (e.g., gibberellins, kinetin) to seeds (Finch-Savage et al., 1991; Nelson and Sharples, 1980; Persson, 1988). These studies were primarily designed to improve seed germination for various species. Several plant growth regulators including paclobutrazol were also applied to germinated seeds by transferring seeds to gels (magnesium silicate) containing growth regulators (Pombo et al. 1985). The systemic properties of paclobutrazol and other triazoles (Davis et al., 1988) may allow the application of growth retardants to seeds with no effect on seed germination. The objective of this study was to compare germination, seedling survival, and seedling height for two bedding plant species (marigold, geranium) and one vegetable species (tomato) after soaking their seeds in varying paclobutrazol solutions at three different soaking times.

\section{Material and Methods}

Seeds of 'Bonanza Gold' marigold, 'Cherry Orbit' geranium, and 'Sun 6108' tomato were soaked in water or paclobutrazol solutions at 500 or $1000 \mathrm{mg} \cdot \mathrm{L}^{-1}$ for 6,16 , or $24 \mathrm{~h}$. Nonsoaked seeds were used as a con- trol. Seeds were soaked in a $50-\mathrm{mL}$ glass beaker containing $20 \mathrm{~mL}$ of the appropriate paclobutrazol solution and 400 seeds. The beaker was agitated constantly during the soaking period. After soaking, seeds were dried for at least $16 \mathrm{~h}$ at $25^{\circ} \mathrm{C}$ on an open bench.

A laboratory germination was conducted on four replications of 50 seeds each per treatment, and placed in standard 10 \{xtimesx\} 10 $\mathrm{cm}$ plastic sandwich boxes. Two sheets of blue blotter paper (Anchor Paper Co., St. Paul, Minn.) were used in each box to provide adequate moisture for germination and each box received $12 \mathrm{~mL}$ distilled water before seeds were placed on the moistened blotters. Seeds were germinated in Hoffman germinators (Hoffman Manufacturing, Albany, Ore.) as described in the Rules for Testing Seeds (Association of Official Seed Analysts, 1993). Germinated seeds were counted twice. Normal seedlings were removed at the first count ( $7 \mathrm{~d}$ for geranium, $4 \mathrm{~d}$ for marigold, and $5 \mathrm{~d}$ for tomato seeds) and the boxes were returned to the germinators until the conclusion of their test period ( $14 \mathrm{~d}$ for geranium, $7 \mathrm{~d}$ for marigold, and $14 \mathrm{~d}$ for tomato seeds).

Treated and nontreated seeds were sown one seed per cell in 288 plug trays (cell depth $=3.1 \mathrm{~cm}$ ) filled with Sunshine LP5 (Sun Gro Horticulture, Bellevue, Wash.) plug mix. After sowing, seeds were covered with a small portion of the plug medium and placed under an intermittent light mist at $25^{\circ} \mathrm{C}$ for 2 to $5 \mathrm{~d}$. Plants were then moved to a greenhouse bench (temperature setting $22^{\circ} \mathrm{C}$ ) and irrigated as needed with tap water. Plugs were fertilized with a 20N-8.7P-16.7K liquid fertilizer (Peters Professional ${ }^{\circledR}$ water-soluble fertilizer; Scotts-Sierra Horticultural Products Co., Marysville, Ohio) at a rate of 200 $\mathrm{mg} \cdot \mathrm{L}^{-1}$ every third watering. The experiments were conducted in a completely randomized design using 200 seeds per treatment with four replications of 50 seeds each. Percentage of usable plugs and seedling height (the distance from the plug tray and the top of the seedling), were measured 16,26 , and $36 \mathrm{~d}$ after sowing. Plugs with no deformities, healthy and with symptoms of active growth were considered usable.

Rate responses to the PGR on laboratory germination, seedling survival, and plant height were determined by regression analysis using the general linear method procedure of SAS (SAS Institute, Cary, N.C.). Single degree of freedom contrasts were used to evaluate treatment effects. The effect of water soaking (water-only soaked seeds vs. nonsoaked seeds or true control) on the same characteristics, was evaluated with means comparison by LSD.

\section{Results and Discussion}

Increasing paclobutrazol concentrations reduced laboratory germination in all but two cases: geranium (16 h imbibition) and marigold (6 h imbibition) (Table 1). Paclobutrazol soaking solutions had no effect on the percentage of usable transplants (plugs) of geranium 
when seeds were soaked for 6 or $16 \mathrm{~h}$ (Table $2)$. However, when seeds were soaked for $24 \mathrm{~h}$, the percentage of usable transplants decreased with increasing the concentration of paclobutrazol. A similar effect was measured on marigolds (Table 2). Percentage of usable tomato seedlings was not affected by higher concentrations and longer soaking times (Table 2). Water imbibition (water only treatment) of seeds had no effect on marigold, geranium, and tomato percentage of usable transplants. No significant differences were found between the control (no soaking) and the water-only soaking treatment (results not shown).

Table 1. Percentage of germination of tomato ('Sun 6108'), geranium ('Cherry Orbit'), and marigold ('Bonanza Gold') seeds soaked in water or two paclobutrazol (Bonzi' ${ }^{\mathrm{TM}}$ ) solutions (500 or $1000 \mathrm{mg} \cdot \mathrm{L}^{-1}$ ) after 5 and $14 \mathrm{~d}$ for tomato, 7 and $14 \mathrm{~d}$ for geranium, and 4 and $7 \mathrm{~d}$ for marigold.

\begin{tabular}{|c|c|c|c|c|c|c|}
\hline \multirow[b]{3}{*}{ Treatment } & \multicolumn{6}{|c|}{ Imbibition time } \\
\hline & \multicolumn{2}{|c|}{$6 \mathrm{~h}$} & \multicolumn{2}{|c|}{$16 \mathrm{~h}$} & \multicolumn{2}{|c|}{$24 \mathrm{~h}$} \\
\hline & $5 \mathrm{~d}$ & $14 \mathrm{~d}$ & $5 \mathrm{~d}$ & $14 \mathrm{~d}$ & $5 \mathrm{~d}$ & $14 \mathrm{~d}$ \\
\hline & \multicolumn{6}{|c|}{ Tomato } \\
\hline Water only & 99 & 99 & 98 & 100 & 94 & 100 \\
\hline $500 \mathrm{mg} \cdot \mathrm{L}^{-1}$ & 22 & 77 & 29 & 78 & 13 & 78 \\
\hline $1000 \mathrm{mg} \cdot \mathrm{L}^{-1}$ & 21 & 83 & 24 & 86 & 38 & 92 \\
\hline \multicolumn{7}{|l|}{ Significance } \\
\hline Linear model & $* *$ & ** & $* *$ & $* *$ & $* *$ & $* *$ \\
\hline \multirow[t]{3}{*}{ Quadratic model } & $*$ & $*$ & $*$ & $*$ & $* *$ & $*$ \\
\hline & \multicolumn{6}{|c|}{ Geranium } \\
\hline & $7 \mathrm{~d}$ & $14 \mathrm{~d}$ & $7 \mathrm{~d}$ & $14 \mathrm{~d}$ & $7 \mathrm{~d}$ & $14 \mathrm{~d}$ \\
\hline Water only & 89 & 99 & 92 & 99 & 46 & 98 \\
\hline $500 \mathrm{mg} \cdot \mathrm{L}^{-1}$ & 10 & 96 & 67 & 96 & 2 & 93 \\
\hline $1000 \mathrm{mg} \cdot \mathrm{L}^{-1}$ & 1 & 84 & 40 & 96 & 0 & 17 \\
\hline \multicolumn{7}{|l|}{ Significance } \\
\hline Linear model & $* *$ & $* *$ & $* *$ & $\mathrm{NS}$ & $* *$ & $* *$ \\
\hline \multirow[t]{3}{*}{ Quadratic model } & NS & NS & NS & NS & NS & NS \\
\hline & \multicolumn{6}{|c|}{ Marigold } \\
\hline & $4 \mathrm{~d}$ & $7 \mathrm{~d}$ & $4 \mathrm{~d}$ & $7 \mathrm{~d}$ & $4 \mathrm{~d}$ & $7 d$ \\
\hline Water only & 76 & 92 & 75 & 92 & 78 & 91 \\
\hline $500 \mathrm{mg} \cdot \mathrm{L}^{-1}$ & 80 & 92 & 76 & 91 & 56 & 88 \\
\hline $1000 \mathrm{mg} \cdot \mathrm{L}^{-1}$ & 60 & 88 & 44 & 71 & 43 & 76 \\
\hline \multicolumn{7}{|l|}{ Significance } \\
\hline Linear model & $*$ & AS & $* *$ & $*$ & ** & * \\
\hline Quadratic model & NS & NS & NS & NS & NS & NS \\
\hline
\end{tabular}

Q*, *,**Nonsignificant, significant, and highly significant, respectively. Significant differences between treatment effects were analyzed by regression analysis.

Table 2. Percentage of seedling survival from tomato ('Sun 6108'), geranium ('Cherry Orbit'), and marigold ('Bonanza Gold') seeds soaked in water or two paclobutrazol $\left(\right.$ Bonzi $\left.^{\mathrm{TM}}\right)$ solutions (500 or $1000 \mathrm{mg} \cdot \mathrm{L}^{-1}$ ) prior to sowing in 288 plug trays.

\begin{tabular}{|c|c|c|c|c|c|c|c|c|c|}
\hline \multirow[b]{3}{*}{ Treatment } & \multicolumn{9}{|c|}{ Seedling survival (\%) } \\
\hline & \multicolumn{3}{|c|}{$6 \mathrm{~h}$ imbibition } & \multicolumn{3}{|c|}{$16 \mathrm{~h}$ imbibition } & \multicolumn{3}{|c|}{$24 \mathrm{~h}$ imbibition } \\
\hline & $16 \mathrm{~d}$ & $26 \mathrm{~d}$ & $36 \mathrm{~d}$ & $16 \mathrm{~d}$ & $26 \mathrm{~d}$ & $36 \mathrm{~d}$ & $16 \mathrm{~d}$ & $26 \mathrm{~d}$ & $36 \mathrm{~d}$ \\
\hline & \multicolumn{9}{|c|}{ Tomato } \\
\hline Water only & 97 & 97 & 97 & 96 & 97 & 97 & 99 & 99 & 99 \\
\hline $500 \mathrm{mg} \cdot \mathrm{L}^{-1}$ & 99 & 97 & 97 & 95 & 95 & 95 & 94 & 95 & 95 \\
\hline $1000 \mathrm{mg} \cdot \mathrm{L}^{-1}$ & 99 & 95 & 95 & 93 & 95 & 95 & 98 & 98 & 98 \\
\hline \multicolumn{10}{|l|}{ Significance } \\
\hline Linear model & NS & $\mathrm{NS}$ & NS & $*$ & NS & NS & NS & NS & NS \\
\hline \multirow[t]{2}{*}{ Quadr. model } & $*$ & NS & NS & NS & AS & NS & * & NS & NS \\
\hline & \multicolumn{9}{|c|}{ Geranium } \\
\hline Water only & 96 & 97 & 97 & 97 & 99 & 99 & 97 & 99 & 99 \\
\hline $500 \mathrm{mg} \cdot \mathrm{L}^{-1}$ & 97 & 97 & 97 & 95 & 97 & 97 & 94 & 98 & 98 \\
\hline $1000 \mathrm{mg} \cdot \mathrm{L}^{-1}$ & 97 & 97 & 97 & 94 & 98 & 98 & 56 & 71 & 80 \\
\hline \multicolumn{10}{|l|}{ Significance } \\
\hline Linear model & NS & AS & AS & NS & NS & NS & ** & ** & $* *$ \\
\hline \multirow[t]{2}{*}{ Quadr. model } & AS. & AS & As. & AS & AS & AS & $* *$ & $* *$ & AS \\
\hline & \multicolumn{9}{|c|}{ Marigold } \\
\hline Water only & 97 & 97 & 97 & 97 & $97^{\circ}$ & 97 & 98 & 97 & 97 \\
\hline $500 \mathrm{mg} \cdot \mathrm{L}^{-1}$ & 95 & 97 & 97 & 99 & 99 & 99 & 96 & 97 & 97 \\
\hline $1000 \mathrm{mg} \cdot \mathrm{L}^{-1}$ & 96 & 95 & 95 & 94 & 96 & 96 & 87 & 94 & 94 \\
\hline \multicolumn{10}{|l|}{ Significance } \\
\hline Linear model & NS & NS & NS & NS & NS & NS & $* *$ & $*$ & $*$ \\
\hline Quadr. model & AS & AS & AS & NG & * & $*$ & AS & AS & AS \\
\hline
\end{tabular}

W, ${ }^{*}, * *$ Nonsignificant, significant, and highly significant, respectively. Significant differences between treatment effects were analyzed by regression analysis.

All seedlings from paclobutrazol-treated seeds appeared to have greener foliage. Significant trends in plug height reduction were measured with increasing concentrations of paclobutrazol (Table 3) for all three dates. When seeds were imbibed 6,16 , or $24 \mathrm{~h}$, seedling heights were reduced by $31 \%, 31 \%$, and $40 \%$, respectively, for tomato; $61 \%, 37 \%$, and $76 \%$, respectively, for geranium; and $30 \%$, $38 \%$, and $41 \%$, respectively, for marigold. Water imbibition of tomato and marigold seeds (water-only) had no effect on seedling height (data not shown).

These results indicate that the seedling height of selected species may be controlled by soaking seeds in paclobutrazol. The primary mode of action of paclobutrazol is by inhibition of gibberellin biosynthesis (Davis et al., 1988). Based on these results, it may be hypothesized that paclobutrazol may adhere to the seedcoats rather than diffuse into the seed. It has been shown that tomato, pepper, leek, and onion seeds have a semipermeable layer in the seedcoats (Beresniewicz et al., 1995a, 1995b). This layer, located at the innermost layer of the seedcoats, has been found to be permeable to water while inhibiting amino acid leakage or uptake of tetrazolium or lanthanum salts. In the case of seeds treated with paclobutrazol, it is speculated that after sowing, the active ingredient likely diffuses from the seedcoats into the growing medium and is then absorbed by the seedling root after germination and emergence. In the case of treatments where seeds remain in the paclobutrazol solution for longer periods, it is possible that a greater amount of PGR moves inside the seed.

It can be also speculated that the reduction in laboratory germination may be due to the movement of paclobutrazol from the seedcoat to the blotter paper, where it is concentrated around the germinating seeds reaching levels that are inhibitory. When similarly treated seeds are sown in the plug cell, paclobutrazol moves into the adsorbent planting medium before it is taken up by the germinating seed. In future work, other laboratory germination methods such as the sand test may be needed to obtain a reliable measure of seed quality.

Further research is required to establish appropriate plant growth regulator concentrations and soaking times. Ornamental crops such as Cosmos sp. and Celosia sp. that have long hypocotyls should be pretested with paclobutrazol and other plant growth regulators. Persistence of the growth regulator in the plants should also be explored. Observation of plants after transplanting seems to indicate that plants from seeds treated with $1000 \mathrm{mg} \cdot \mathrm{L}^{-1}$ paclobutrazol remained shorter than plants from other treatments (water only or $500 \mathrm{mg} \cdot \mathrm{L}^{-1}$ paclobutrazol) for a longer duration.

\section{Literature Cited}

Association of Official Seed Analysts. 1993. Rules for testing seeds. J. Seed Technology. 16:1-113.

Barrett, J.E. 2000. Applying chemical growth regulators, p. 123-124. In S. Carver (ed.). Tips on managing floriculture crop problems. Pests, 
Table 3. Seedling height (cm) of tomato ('Sun 6108'), geranium ('Cherry Orbit'), and marigold ('Bonanza Gold') from seeds soaked in water or two paclobutrazol (Bonzi ${ }^{\mathrm{TM}}$ ) solutions (500 or $1000 \mathrm{mg} \cdot \mathrm{L}^{-1}$ ) prior to sowing in 288 plug trays.

\begin{tabular}{|c|c|c|c|c|c|c|c|c|c|}
\hline \multirow[b]{3}{*}{ Treatment } & \multicolumn{9}{|c|}{ Seedling ht $(\mathrm{cm})$} \\
\hline & \multicolumn{3}{|c|}{$6 \mathrm{~h}$ imbibition } & \multicolumn{3}{|c|}{$16 \mathrm{~h}$ imbibition } & \multicolumn{3}{|c|}{$24 \mathrm{~h}$ imbibition } \\
\hline & $16 \mathrm{~d}$ & $26 \mathrm{~d}$ & $36 \mathrm{~d}$ & $16 \mathrm{~d}$ & $26 \mathrm{~d}$ & $36 \mathrm{~d}$ & $16 \mathrm{~d}$ & $26 \mathrm{~d}$ & $36 \mathrm{~d}$ \\
\hline & \multicolumn{9}{|c|}{ Tomato } \\
\hline Water only & 3.8 & 8.2 & 12.4 & 3.9 & 8.5 & 13.1 & 3.7 & 8.1 & 12.4 \\
\hline $500 \mathrm{mg} \cdot \mathrm{L}^{-1}$ & 2.7 & 5.2 & 8.8 & 2.6 & 4.9 & 8.1 & 2.8 & 5.0 & 8.9 \\
\hline $1000 \mathrm{mg} \cdot \mathrm{L}^{-1}$ & 2.6 & 4.7 & 8.5 & 2.6 & 5.3 & 9.0 & 2.7 & 5.1 & 7.9 \\
\hline \multicolumn{10}{|l|}{ Significance } \\
\hline Linear model & $* *$ & $* *$ & $* *$ & $* *$ & $* *$ & $* *$ & $* *$ & $* *$ & $* *$ \\
\hline Quadratic model & $* *$ & $*$ & $* *$ & $* *$ & $* *$ & $* *$ & $* *$ & $* *$ & $* *$ \\
\hline \multicolumn{10}{|c|}{ Geranium } \\
\hline Water only & 2.3 & 5.1 & 9.0 & 2.3 & 4.7 & 8.2 & 2.1 & 4.9 & 8.3 \\
\hline $500 \mathrm{mg} \cdot \mathrm{L}^{-1}$ & 1.2 & 2.8 & 5.4 & 1.4 & 3.0 & 5.9 & 1.3 & 2.1 & 3.8 \\
\hline $1000 \mathrm{mg} \cdot \mathrm{L}^{-1}$ & 0.9 & 1.9 & 3.5 & 1.1 & 2.6 & 5.2 & 0.6 & 1.2 & 2.0 \\
\hline \multicolumn{10}{|l|}{ Significance } \\
\hline Linear model & $* *$ & $* *$ & $* *$ & $* *$ & $* *$ & $* *$ & $* *$ & $* *$ & $* *$ \\
\hline \multirow[t]{2}{*}{ Quadratic model } & AS & $*$ & $* *$ & $* *$ & $* *$ & $* *$ & AS & $* *$ & $* *$ \\
\hline & \multicolumn{9}{|c|}{ Marigold } \\
\hline Water only & 3.2 & 6.7 & 8.5 & 3.3 & 6.3 & 8.6 & 3.4 & 6.3 & 8.6 \\
\hline $500 \mathrm{mg} \cdot \mathrm{L}^{-1}$ & 2.4 & 5.3 & 6.5 & 2.1 & 4.9 & 6.1 & 2.1 & 5.0 & 6.2 \\
\hline $1000 \mathrm{mg} \cdot \mathrm{L}^{-1}$ & 1.9 & 4.5 & 5.9 & 2.0 & 4.2 & 5.3 & 1.9 & 3.8 & 5.1 \\
\hline \multicolumn{10}{|l|}{ Significance } \\
\hline Linear model & $* *$ & $* *$ & $* *$ & $* *$ & $* *$ & $* *$ & $* *$ & $* *$ & $* *$ \\
\hline Quadratic model & $\mathrm{NS}$ & $*$ & $* *$ & $* *$ & $* *$ & $* *$ & $* *$ & NS & $* *$ \\
\hline
\end{tabular}

${ }^{2}$ Significant differences between treatment effects were by regression analysis.

$\mathbb{H}_{\mathbb{S}, *, * *}$ Nonsignificant, significant and highly significant, respectively.

Diseases, and Growth Control. OFA Services. Columbus, Ohio.

Barrett, J.E., C.A. Bartuska and T.A. Nell. 1994. Comparison of paclobutrazol drenches and spike application for height control of potted floricultural crops. HortScience 29:180-182.

Barrett, J.E. and T.A. Nell. 1989. Comparison of paclobutrazol and uniconazole on floriculture crops. Acta Hort. 251:275-280.
Beresniewicz, M.M., A.G. Taylor, M.C. Goffinet, and W.D. Koeller. 1995. Chemical nature of a semipermeable layer in seed coats of leek, onion (Liliaceae), tomato and pepper (Solanaceae). Seed Sci. \& Technol. 23:135-145.

Beresniewicz, M.M., A.G. Taylor, M.C. Goffinet, and B.T. Terhune. 1995. Characterization and location of a semipermeable layer in seed coats of leek and onion (Liliaceae), tomato and pep- per (Solanaceae). Seed Sci. \& Technol. 23:123134.

Dasoju, S., M.R. Evans, and B.E. Whipker. 1998. Paclobutrazol drench activity in coir-and peatbased root substrates. HortTechnology 8:595598.

Davis, T.D., F.L. Steffons, and N. Sankhla. 1988. Triazole plant growth regulators, p. 63-105. In: J. Janick (ed.). Hort. Rev. vol. 10. Timber Press, Portland, Ore

Einert, A.E. 1976. Slow-release ancymidol for poinsettia by impregnation of clay pots. HortScience 1:374-375.

Finch-Savage, W.E., D. Gray, and G.M. Dickson. 1991. The combined effects of osmotic priming with plant growth regulator and fungicide soaks on the seed quality of five bedding plant species. Seed Sci. \& Technol. 19:495-503.

Million, J.B., J.E. Barrett, T.A. Nell, and D.G. Clark. 1998. Influence of media components on efficacy of paclobutrazol in inhibiting growth of broccoli and petunia. HortScience 33:852856.

Nelson, J.M. and G.C. Sharples. 1980. Stimulation of tomato, pepper, and sugarbeet seed germination at low temperatures by growth regulators. J. Seed Technol. 5:62-68.

Persson, B. 1988. Enhancement of seed germination by plant growth regulators infused via acetone. Seed Sci. \& Technol. 16:391-404.

Pombo, G., M.D. Orzolek, L.D. Tukey, and T.P. Pyzik. 1985. The effect of paclobutrazol, daminozide, glyphosate and 2,4-D in gel on the emergence and growth of germinated tomato seeds. J. Hort. Sci. 60:353-357.

Sanderson, K.C., W.C. Martin, Jr., and J. McGuire. 1988. Comparison of paclobutrazol tablets, drenches, gels, capsules, and sprays on chrysanthemum growth. HortScience 23:1008-1009.

Whipker, B.E. and P.A. Hammer. 1997. Efficacy of ancymidol, paclobutrazol, and uniconazole on growth of tuberous-rooted dahlias. HortTechnology 7:269-273. 